\title{
Reforming the Exhaust Passage of Low-pressure Cylinder for 330MW Steam Turbine
}

\author{
YAN Tao ${ }^{1}$, CAI Wen ${ }^{1}$, CHEN Wen ${ }^{1}$, LU Jin ${ }^{1}$, Yang Hong-yan ${ }^{2}$ \\ ${ }^{1}$ Jiang Xi Electric Power Science \& Research Institute of National Grid, Nanchang 330096, Jiangxi Province, China \\ ${ }^{2}$ Shanghai Pengken Energy Technology Co.LTD, Shanghai 200090, China
}

\begin{abstract}
In concern of the velocity distribution of the exhaust passage of 330MW turbine is not uniform, which results in higher the upper temperature difference of the condenser and higher exhaust pressure. It is introduced in this article that based on mathematical simulation, steam-equalizing equipment is augmented at the exhaust area of the condenser which makes the decrease in the steam resistance, much more uniform velocity distribution, and the increase of the heat transfer coefficient. By comparison of the condenser performance test before the amending and after, the result shows that after the amending, the upper temperature difference of the condenser and the exhaust pressure decreases dramatically.
\end{abstract}

\section{Introduction}

A steam turbine manufactured by Beijing BEIZHONG Steam Turbine Generator Co.,Ltd, whose model is $\mathrm{N} 330-17.75 / 540 / 540$, is equipped at a power plant, auxiliary with $\mathrm{N}-18000$ condenser, whose cooling area is $18000 \mathrm{~m}^{3}$, and the length of each cooling tube is $12420 \mathrm{~mm}$. Since the turbine was put into operation in 2008, there have been problems, such as big terminal temperature difference of condenser and high exhaust pressure of the low-pressure cylinder(low vacuum), which leads to an increase in both heat rate and coal consumption rate of the turbine unit.

\section{Analysis}

The possible reasons for the phenomena presented above are insufficient cooling water flow, dirty cooling tubes of the condenser, and uneven flow field at the throat outlet of the condenser. The exhaust passage model of the turbine is established by a professional software Gambit in this article, and the flow field model of The exhaust passage model is simulated by a software Fluent. The simulation results show that the flow field distribution of the exhaust steam in the condenser is not reasonable (shown in Figure 1), which restricts the cooling effect of the condenser to a certain extent and has the potential for further optimization. Fig. 1 is the velocity contour map of steam turbine cross-section at the outlet of the lower half of the condenser (condenser cooling pipe inlet) before the exhaust passage is optimized. The straight line on the axis of the turbine is the semi-side symmetrical exhaust passage. As can be seen from the figure, there is a large variety of low-velocity area (dark blue area in the figure, whose speed is below $10 \mathrm{~m} / \mathrm{s}$ ) at the inlet of the tube bundle under the original channel, and the heat transfer coefficient in this area must be small.

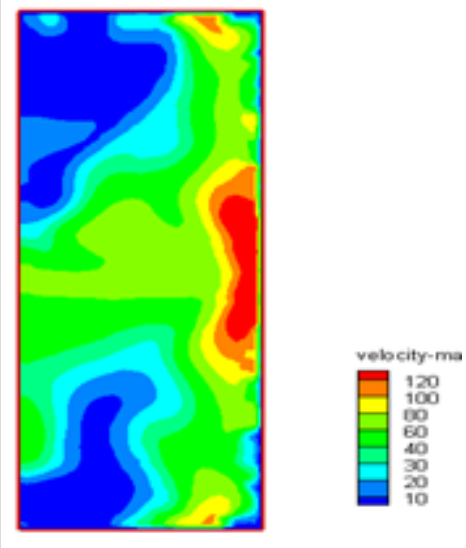

Figure 1. Original exhaust steam velocity chart of LP cylinder

\section{Optimal reform for the exhaust passage}

If measures are taken to distribute part of the steam in the high-speed steam (velocity above $50 \mathrm{~m} / \mathrm{s}$ ) to the above low-speed zone (corresponding to "peak load shifting"), the heat transfer coefficient of the pipe bundle in the area will increase and the overall heat transfer of the condenser will increase. The coefficient and heat transfer effect must be strengthened.

According to the simulated calculation, the distribution of the steam flow field at the inlet of the condenser tube under the original structure is targeted at the appropriate position in the neck of the condenser, and the streamlined oblique, flat vertical, and straight inclined are installed. The flow guiding and equalizing devices were set up to properly guide the original steam 
flow and optimize the steam flow field, so that the turbine exhaust steam flow into the flow field of the cooling pipe bundle tends to be reasonable. Exhaust passage optimization measures should include the following:

(1) All baffles are arranged in the upper half of the condenser in the connecting neck, in which a row of inclined plates is perpendicular to the axis of the turbine, and four rows of vertical plates are parallel to the axis of the turbine (Figure 2). Both governing end and electrical end of the LP cylinder are symmetrically arranged.

(2) Inclined plates are set as follows. The inlet side is vertical, and the angle between the outlet side and the vertical direction is 30 degrees. The exit side of the swash plate is located on the cross-section of the square neck outlet, and the horizontal distance of the entrance side from the end wall (tune end or electric end) is $650 \mathrm{~mm}$; the total length of the swash plate (length direction of the cooling pipe extension) is $6600 \mathrm{~mm}$, and it is symmetrically arranged according to the center.

(3) Vertical plates are set as follows. The vertical plate is divided into four pieces, whose height is $940 \mathrm{~mm}$, and length is $1550 \mathrm{~mm}$, upright arranged in the square connecting neck between the upper and lower two rows of struts. There are steam extraction on the side of the tube, the distance between the two vertical plates from the center line is $1500 \mathrm{~mm}$ and $2900 \mathrm{~mm}$ differently, while the distance is $1600 \mathrm{~mm}$ and $2900 \mathrm{~mm}$ from the center line for non-extraction side. The distance between the four vertical plates from the electrical end (or governing end) is $1610 \mathrm{~mm}$. The above is just an arrangement on the outlet side, and the other outlet arrangement is symmetrical with this. Each of the four vertical plates on both sides is actually a two-by-two combination of $940 \times 3100 \mathrm{~mm}$.

(4) The material of the diversion device is made of stainless steel and is resistant to erosion. The rooting position of the deflector is the frame support tube in the throat of the condenser, supported by the $\varphi 63.5 * 5$ tubes.

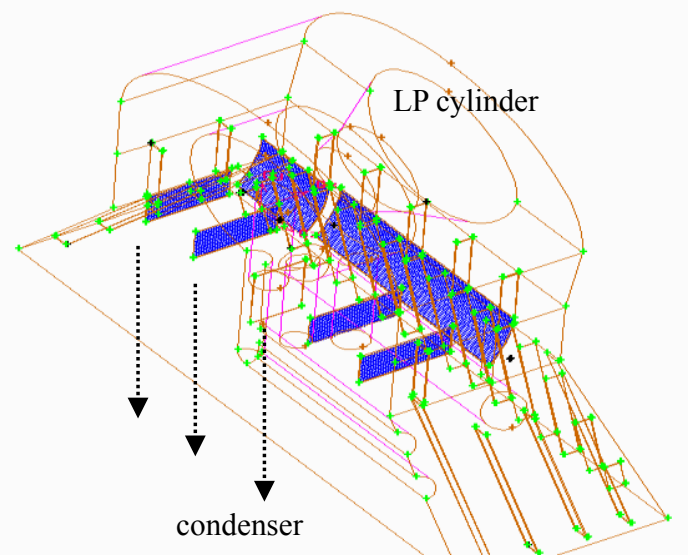

The shadow is diversion device

Figure 2. reform drawing for the exhaust passage

After optimization measures are taken, steam flow of the exhaust passage is more uniform, while the thermal load distribution of condenser cooling tube bundles in the longitudinal and transverse directions is reasonable, and the area of the low-speed area is significantly reduced, as shown in figure 3.

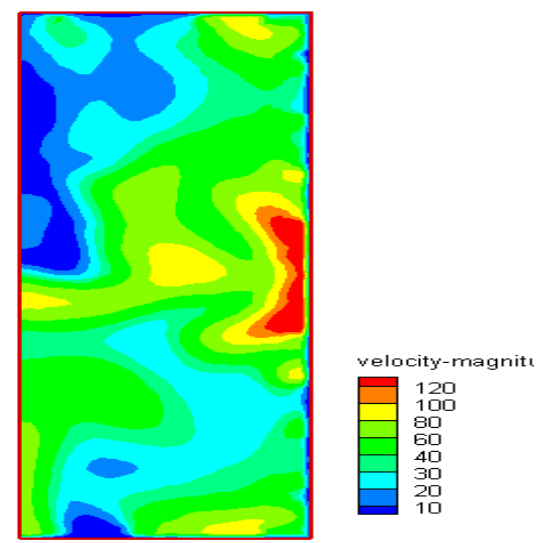

Figure 3. Exhaust steam velocity chart of LP cylinder after reform

\section{Results}

The results in Table 1 show that after the reform measures are fulfilled on the turbine, both the terminal temperature difference of the condenser and the exhaust pressure of LP cylinder dropped significantly under various operating conditions, most of which happens at $320 \mathrm{MW}$ condition, $\mathrm{t}$ the terminal temperature difference of the condenser decreased by $1.22^{\circ} \mathrm{C}$ while exhaust pressure by $0.51 \mathrm{kPa}$.

Table 1. comparison of the condenser performance before and after reform

\begin{tabular}{|l|c|c|c|c|c|}
\hline Power & $\mathrm{MW}$ & 320 & 300 & 270 & 240 \\
\hline Revised Temperature difference before & ${ }^{\circ} \mathrm{C}$ & 6.73 & 4.83 & 4.55 & 4.23 \\
\hline Revised Temperature difference after & ${ }^{\circ} \mathrm{C}$ & 5.51 & 4.03 & 3.69 & 3.28 \\
\hline Difference between before and after & ${ }^{\circ} \mathrm{C}$ & 1.22 & 0.80 & 0.86 & 0.95 \\
\hline Revised exhaust pressure before & $\mathrm{kPa}$ & 7.25 & 6.38 & 5.97 & 5.54 \\
\hline
\end{tabular}




\begin{tabular}{|l|c|c|c|c|c|}
\hline Revised exhaust pressure after & $\mathrm{kPa}$ & 6.74 & 5.97 & 5.62 & 5.24 \\
\hline Difference between before and after & $\mathrm{kPa}$ & 0.51 & 0.41 & 0.35 & 0.30 \\
\hline
\end{tabular}

Table 2. calculated back pressure under various conditions before and after the reform(designed water flow of $39200 \mathrm{~m}^{3} / \mathrm{h}$ )

\begin{tabular}{|c|c|c|c|c|c|c|c|c|c|}
\hline \multirow{2}{*}{ Heat load } & \multirow{2}{*}{ item } & \multirow{2}{*}{ unit } & \multicolumn{7}{|c|}{ Circulating water inlet temperature } \\
\hline & & & $10^{\circ} \mathrm{C}$ & $15^{\circ} \mathrm{C}$ & $20^{\circ} \mathrm{C}$ & $23.5^{\circ} \mathrm{C}$ & $25^{\circ} \mathrm{C}$ & $30^{\circ} \mathrm{C}$ & $33^{\circ} \mathrm{C}$ \\
\hline \multirow{3}{*}{$100 \%$} & Back pressure after & $\mathrm{kPa}$ & 3.48 & 4.35 & 5.53 & 6.57 & 7.08 & 9.08 & 10.55 \\
\hline & Back pressure before & $\mathrm{kPa}$ & 3.78 & 4.68 & 5.90 & 6.98 & 7.50 & 9.59 & 11.11 \\
\hline & difference & $\mathrm{kPa}$ & 0.30 & 0.32 & 0.36 & 0.40 & 0.42 & 0.50 & 0.56 \\
\hline \multirow{3}{*}{$90 \%$} & Back pressure after & $\mathrm{kPa}$ & 3.15 & 3.98 & 5.10 & 6.08 & 6.56 & 8.45 & 9.83 \\
\hline & Back pressure before & $\mathrm{kPa}$ & 3.40 & 4.25 & 5.40 & 6.42 & 6.91 & 8.87 & 10.30 \\
\hline & difference & $\mathrm{kPa}$ & 0.25 & 0.27 & 0.30 & 0.34 & 0.35 & 0.42 & 0.48 \\
\hline \multirow{3}{*}{$80 \%$} & Back pressure after & $\mathrm{kPa}$ & 2.85 & 3.64 & 4.69 & 5.62 & 6.07 & 7.85 & 9.15 \\
\hline & Back pressure before & $\mathrm{kPa}$ & 3.06 & 3.86 & 4.94 & 5.90 & 6.36 & 8.20 & 9.55 \\
\hline & difference & $\mathrm{kPa}$ & 0.20 & 0.22 & 0.25 & 0.28 & 0.29 & 0.35 & 0.40 \\
\hline \multirow{3}{*}{$70 \%$} & Back pressure after & $\mathrm{kPa}$ & 2.58 & 3.32 & 4.32 & 5.19 & 5.61 & 7.29 & 8.51 \\
\hline & Back pressure before & $\mathrm{kPa}$ & 2.74 & 3.50 & 4.52 & 5.41 & 5.85 & 7.58 & 8.84 \\
\hline & difference & $\mathrm{kPa}$ & 0.16 & 0.18 & 0.20 & 0.23 & 0.24 & 0.29 & 0.33 \\
\hline \multirow{3}{*}{$60 \%$} & Back pressure after & $\mathrm{kPa}$ & 2.33 & 3.03 & 3.96 & 4.78 & 5.18 & 6.76 & 7.91 \\
\hline & Back pressure before & $\mathrm{kPa}$ & 2.46 & 3.17 & 4.13 & 4.97 & 5.38 & 6.99 & 8.18 \\
\hline & difference & $\mathrm{kPa}$ & 0.13 & 0.14 & 0.16 & 0.18 & 0.19 & 0.23 & 0.26 \\
\hline \multirow{3}{*}{$50 \%$} & Back pressure after & $\mathrm{kPa}$ & 2.10 & 2.76 & 3.64 & 4.41 & 4.79 & 6.27 & 7.35 \\
\hline & Back pressure before & $\mathrm{kPa}$ & 2.20 & 2.87 & 3.76 & 4.55 & 4.93 & 6.45 & 7.56 \\
\hline & difference & $\mathrm{kPa}$ & 0.10 & 0.11 & 0.12 & 0.14 & 0.15 & 0.18 & 0.20 \\
\hline
\end{tabular}

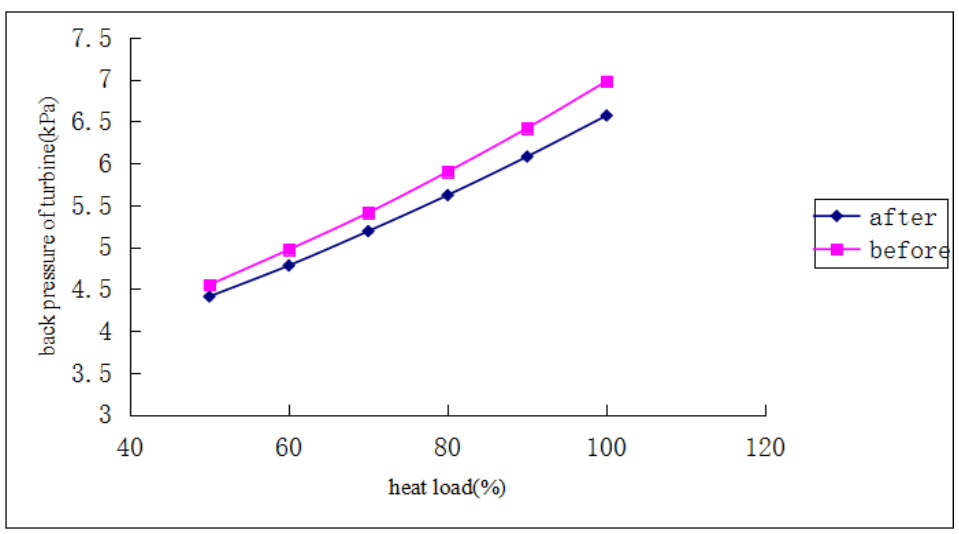

Figure 4. back pressure of cylinder before and after the reform (designed water flow of $39200 \mathrm{~m}^{3} / \mathrm{h}$ and inlet water temperature of $23.5^{\circ} \mathrm{C}$ ) 
Under the designed circulating water flow volume at various conditions, the back pressure of the turbine listed in table 2 decreases dramatically by comparing before and after the reform that the performance of the condenser increases corresponding. For example, When the circulating water inlet water temperature is $23.5^{\circ} \mathrm{C}$, the back pressure drops by $0.40 \mathrm{kPa}$, while it drops by $0.56 \mathrm{kPa}$ at $33^{\circ} \mathrm{C}$. Figure 4 shows the back pressure curve by data fitting before and after the modification of the $\# 9$ steam turbine exhaust passage under the designed circulating water inlet flow, inlet water temperature of $23.5^{\circ} \mathrm{C}$, and at different thermal loads of the condenser.

\section{Conclusion}

By optimizing and reforming the steam turbine exhaust passage, a flow equalizing device is installed at the condenser throat. Simulation results show that the low velocity area of the exhaust passage can be significantly reduced and the overall heat transfer coefficient can be improved. The test results show that after the reforming, the terminal temperature difference of the condenser is reduced, the exhaust pressure is also reduced, and the economic efficiency of the unit is improved, which has important significance for promotion.

\section{References}

1. Fu wenfeng, etc. Three-dimensional Numerical Flow Simulation and Structure Optimization of Low-pressure Last Stage Exhaust Passage in a 600MW Steam Turbine, Proceedings of the CSEE,2014,13(14):2267-2272.

2. 2.Song Zhen, etc. Numerical simulation of coupled flow in exhaust passage of steam turbine, Journal of Southeast University (Natural Science Edition), 2015,45(4):701-706.

3. CAo Lihua, etc. Numerical Study on Effectiveness of Installing Guide Device into Exhaust Passage of a 600MW Steam Turbine, Journal of Chinese Society of Power Engineering, 2015,35(5):366-371.

4. ZHOU lan-xin, etc. Numerical Study on the Performance of Exhaust Steam Passage with Different Guide Baffles, Turbine Technology,2015,57(1):33-36.

5. White A J. A Comparison of modelling methods for polydispersed wet-steam flow, International Journal for Numerical Methods in Engineering, 2003,57(6):819-834. 